\title{
Rekontruksi Perhitungan Harga Pokok Produksi pada UMKM Eraclassic
}

\author{
(Reconstruction Calculation of The Cost of Goods Manufactured in UMKM Eraclassic) \\ Bariro* dan Aisa Tri Agustini \\ Jurusan Akuntansi, Fakultas Ekonomi dan Bisni, Universitas Jember (UNEJ) \\ Jln. Kalimantan 37, Jember 68121 \\ E-mail: bariro65@gmail.com
}

\begin{abstract}
Abstrak
Penelitian ini bertujuan untuk merekonstruksi perhitungan harga pokok produksi tas pada UMKM Eraclassic yang ada di Kabupaten Gresik. Metode perhitungan harga pokok produksi tersebut menggunakan metode job order costing. Data dalam penelitian dikumpulkan melalui observasi, wawancara, dan dokumenter. Metode analisis data yang digunakan dalam penelitian ini adalah deskriptif kualitatif dan kuantitatif. Hasil penelitian menunjukkan bahwa terdapat perbedaan perhitungan harga pokok produksi antara perhitungan yang dilakukan oleh UMKM Eraclassic dengan metode job order costing. Hasil rekonstruksi penghitungan harga pokok produksi menunjukkan pesanan tas selempang, tas gaul dan tas ransel memiliki harga pokok produksi masing-masing sebesar $\mathrm{Rp} 22.680$, Rp 30.189 dan $\mathrm{Rp} 41.707$ per unitnya, hasil tersebut berdampak terhadap laba yang diterima UMKM Eraclassic terlalu rendah sebesar Rp 1.972 per lusin. Berdasarkan hasil analisis, UMKM Eraclassic perlu memperhitungkan unsur-unsur biaya overhead pabrik, biaya depresiasi gedung, kendaraan dan peralatan pabrik. Selain itu, biaya teanaga kerja dan biaya listrik dan telpon dibebankan pada produk berdasarkan kebijakan biaya yang ada pada UMKM Eraclasic. Berdasarkan metode job order costing, biaya tenaga kerja seharusnya dibebankan berdasarkan biaya yang sesungguhnya terjadi, sedangkan biaya listrik dan telpon yang merupakan biaya overhead dibebankan berdasarkan tarif yang ditentukan dimuka dengan dasar pembebanan.
\end{abstract}

Kata Kunci: Harga Pokok Produksi, Job Order Costing, Biaya Produksi, Laba

\begin{abstract}
The objective of this research is to reconstruct manufacturing cost of bag in UMKM Eraclassic located in Gresik Regency, using job order costing method. Data in this research are collected through observation, interviews, and documentaries. Descriptive qualitative and quantitative method will be used to analyze those data. The results shows that there is a differences between the calculation of manufacturing cost by UMKM Eraclassic and calculation using job order costing method. The result of reconstruction calculation shows that sling bag, fungky bag and duffel bag manufacture cost are Rp 22.680, Rp 30.189 , and $\mathrm{Rp} 41.707$ per unit. This results shows that the gross profit accepted by UMKM Eraclassic are Rp 1.972 per dozen, which is too low. Based on those result, UMKM Eraclassic needs to take the manufacturing overhead cost elements, the cost of depreciation of buildings and vehicles and equipment manufacturer into accounts. In addition, based on the existing fee policy on UMKM Eraclasic, direct labor cost and utility cost will be charged to products. Based on job order costing method, direct labor cost should be charged based on the actual cost of the case, while utility expense which is the manufacturing overhead costs will be charged by the rate determined upfront based on basic imposition.
\end{abstract}

Keywords: Manufacturing Cost, Job Order Costing, Cost of Production, Gross Profit

\section{Pendahuluan}

Usaha Mikro Kecil dan Menengah menjadi salah satu senjata pemerintah dalam menggerakkan roda perekonomian. Menurut Sudaryanto et.al, (2012) sebagian besar (hampir mencapai 99 persen) UMKM Di Indonesia merupakan usaha mikro kecil dengan sektor informal yang pada umumnya menggunakan bahan baku lokal dengan pasar lokal sehingga tidak terpengaruh secara langsung oleh krisis global.UMKM menjadi penopang perekonomian mengingat perannya dalam perekonomian yang begitu besar. Mulai dari kontribusi terhadap penerimaan negara hingga penyerapan tenaga kerja.

Meskipun demikian, kerja keras pemerintah dalam upaya membantu mengurangi kesulitan yang dihadapi UMKM dirasa belum maksimal.Masih banyak permasalahan yang dihadapi oleh UMKM. salah satu masalah tersebut yang dihadapi UMKM adalah terkait akuntansi biaya dalam hal perhitungan harga pokok produksi. Akuntansi biaya adalah proses pencatatan, penggolongan, peringkasan dan penyajian biaya pembuatan dan penjualan produk atau jasa, dengan cara-cara tertentu, serta penafsiran terhadapnya (Mulyadi,
2012:7).Metode pengumpulan biaya produksi maupun biaya per unit dipengaruhi oleh karakteristik kegiatan produksi perusahaan. Jika perusahaan berproduksi berdasarkan pesanan, maka pengumpulan harga pokok produksinya dengan menggunakan metode harga pokok pesanan (job order costing). Metode ini mengumpulkan biaya-biaya produksi-biaya bahan baku, biaya tenaga kerja langsung dan biaya overhead pabrik-yang diakumulasikan untuk setiap pesanan tertentu (Siregar et al, 2014:46).

Metode job order costing akan memberikan informasi kepada manajemen terkait harga pokok produksi per pesanan ataupun per unit dalam satu pesanan. Informasi ini dapat dijadikan sebagi dasar pertimbangan dalam menentukan harga jual yang dibebankan kepada pemesan, bahan pertimbangan untuk menerima atau menolak pesanan, alat monitoring realisasi biaya produksi, menghitung laba atau rugi tiap pesanan, serta menentukan harga pokok persediaan produk jadi dan produk dalam proses yang disajikan dalam neraca (Mulyadi, 2012: 39).

\footnotetext{
* Corresponding Author
} 
UMKM Eraclassic adalah salah satu UMKM pengrajin tas Di Kabupaten Gresik. UMKM Eraclassic memiliki prospek usaha yang baik dengan produksi per bulan bisa mencapai 2.000 unit tas. UMKM Eraclassic melakukan kegiatan produksi secara massa dan berdasarkan pesanan dari pelanggan. Berdasarkan data jumlah tas yang di produksi UMKM Eraclassic pada tahun 2016 menyatakan bahwa hampir $95 \%$ dari total produksi merupakan proses produksi yang dilakukan berdasarkan pesanan. Sama hal nya dengan UMKM pada umumnya, UMKM Eraclassic juga tidak begitu paham dengan akuntansi biaya, khusunya dalam menentukan harga pokok produksi. Selama ini UMKM Eraclassic dalam menentukan harga pokok produksi dengan memperhitungkan biaya bahan baku, biaya tenaga kerja dan biaya lain- lain yang meliputi biaya listrik dan telp.

Melihat unsur-unsur biaya produksi yang diperhitungkan oleh UMKM Eraclassic tersebut, kemungkinan UMKM Eraclassic dalam menghitung harga pokok produksi sudah sesuai dengan metode job order costing. Namun kemungkinan masih belum sempurna, yaitu bisa saja masih terdapat unsur biaya produksi yang belum diperhitungkan oleh UMKM Eraclassic sebagai biaya produksi dan mungkin juga terdapat biaya yang seharusnya tidak menjadi unsur biaya produksi tapi oleh UMKM Eraclassic dimasukkan sebagai unsur biaya produksi.Berdasarkan latar belakang diatas, maka peneliti tertarik untuk melakukan rekonstruksi penentuan harga pokok produksi pada UMKM Eraclassic dengan metode pengumpulan biaya produksi job order costing dan metode penentuan biaya produksinya dengan pendekatan full costing.

Berdasarkan latar belakang diatas, maka rumusan masalah dari penelitian ini meliputi: (a) bagaimana perhitungan harga pokok produksi yang selama ini dilakukan oleh UMKM Eraclassic; (b) bagaimana rekonstruksi perhitungan harga pokok produksi dengan Metode Job Order Costing pada UMKM Eraclassic; (c) bagaimana perbandingan hasil perhitungan harga pokok produksi yang selama ini dilakukan oleh UMKM Eraclassic dengan Metode Job Order Costing dan dmpaknya terhadap harga jual dan laba. Tujuan dari penelitian ini adalah untuk mengetahui perhitungan harga pokok produksi yang selama ini dilakukan oleh UMKM Eraclassic, melakukan rekonstruksi perhitungan harga pokok produksi dengan Metode Job Order Costing dan menganalisis perbedaan hasil hasil perhitungan harga pokok produksi yang selama ini dilakukan oleh UMKM Eraclassic dengan Metode Job Order Costing.

\section{Metode}

\section{Rancangan Penelitian}

Metode penelitian yang digunakan dalam penelitian ini adalah metode deskriptif. Jenis penelitiannya yaitu dengan cara studi kasus, yaitu dengan melakukan riset mengenai penerapan metode job order costing dalam menghitung harga pokok produksi pada UMKM Eraclassic.

\section{Objek Penelitian}

Obyek penelitian ini adalah UMKM Eraclassic yang merupakan sebuah usaha mikro kecil dan menengah (UMKM) yang bergerak dalam bidang pembuatan tas. Eraclassic membuat berbagai macam tas berdasarkan pesanan. Eraclassic menerima pesanan dari pemesan kemudian melakukan perhitungan harga pokok produksi untuk memberikan penawaran harga jual pada pemesan. Jika pemesan menyetujui harga yang ditawarkan oleh Eraclassic, maka produksi untuk pesanan akan dilakukan. Produksi Eraclassic beralamatkan di Jalan Jaksa Agung Suprapto $8 \mathrm{H}$ No.6 Gresik.

\section{Jenis Sumber Data}

Jenis data dalam penelitian ini adalah data primer, yaitu data yang diperoleh secarang langsung dilapangan, tanpa melalui media perantara (berasal sari sumber asli), bisa berupa opini subyek baik secara individual maupun kelompok dan hasil dari observasi. Data dalam penenlitian ini diperoleh dari pemilik usaha melalui wawancara dan observasi.

\section{Metode Pengumpulan Data}

Tujuan utama dari sebuah penelitian adalah untuk memperoleh data. Berdasakan tujuan tersebut, maka teknik pengumpulan data menjadi langkah yang paling strategis dalam sebuah penelitian (Sugiyono, 2013: 224). Adapun teknik pengumpulan data dalam penelitian ini meliputi:

\section{(a) Wawancara (Interview)}

Wawancara yang dilakukan peneliti merupakan wawancara semiterstruktur dimana pertanyaan dalam wawancara tidak harus berdasarkan daftar pertanyaan yang telah dibuat.Narasumber dalam penelitian ini adalah Bapak Hidayat yang menjadi pemilik sekaligus pengelola UMKM Eraclassic.

\section{(b) Observasi (Observation)}

Merupakan teknik pengumpulan data dengan cara melakukan pengamatan secara langsung pada objek yang akan diteliti. Kegiatan observasi dalam penelitian ini adalah mengamati bagaimana Eraclassic melakukan perhitungan dalam menentukan harga pokok produksi dan harga jual untuk pesanan yang diterima.

\section{(c) Dokumenter}

Teknik dokumenter dalam penelitian ini dilakukan dengan cara Peneliti mengumpulkan catatan, dokumen atau arsip yang berkaitan dengan biaya-biaya yang dikeluarkan oleh UMKM Eraclassic dalam menyelesaikan pesanan.

\section{Metode Analisis Data}

Metode analisis yang digunakan dalam penelitian ini adalah metode analisis deskriptif kualitatif dan kuantitatif. Metode analisis kuantitatif dilakukan dengan cara menghitung harga pokok produksi yang dinyatakan dalam angka-angka. Sedangkan Metode analisis deskriptif kualitatif dalam penelitian ini digunakan untuk memaparkan dan menjelaskan hasil penelitian dengan membandingkan hasil perhitungan harga pokok produksi berdasarkan perusahaan dengan perhitungan harga pokok produksi berdasarkan teori, serta melihat pengaruhnya terhadap harga jual dan laba perusahaan dengan menggunaan keterangan-keterangan yang tidak dalam bentuk angka.

Tahapan yang dilakukan dalam penenlitian ini diawali dengan menganalisis penentuan harga pokok produksi yang dilakukan oleh UMKM Eraclassic atas pesanan yang diterima, selanjutnya dilakukan analisis terhadap penentuan harga pokok produksi atas pesanan yang diterima dengan menggunakan metode job order costing. Penentuan harga 
pokok produksi dengan metode tersebut terlebih dahulu dilakukan identifikasi terhadap proses produksi beserta biayabiaya yang dikeluarkan untuk melakukan proses produksi. Adapun biaya-biaya dalam metode job order costing meliputi: biaya bahan baku, biaya tenaga kerja langsung dan biaya overhead pabrik. Biaya overhead pabrik adalah biayabiaya yang terjadi di pabrik selain biaya bahan baku maupun biaya tenaga kerja langsung. Biaya bahan penolong, biaya tenaga kerja tidak langsung, biaya sewa pabrik, depresiasi peralatan pabrik, dan asuransi pabrik. Biaya overhead pabrik sulit ditelusur ke suatu produk (Siregar et al, 2014: 29). Selanjutnya, dilakukan analisis perbedaan harga pokok antara perhitungan yang dilakukan oleh UMKM Eraclassic dengan metode job order costing beserta dampaknya terhadap harga jual dan laba. Apabila penentuan harga pokok produksi yang dilakukan oleh UMKM Eraclassic tidak tepat, maka dalam menentukan harga jual dan laba akan mengalami kesalahan. Dengan demikian, selisih nilai antar harga pokok yang dihitung UMKM Eraclassic dengan harga pokok berdasarkan metode job order costing akan mempengaruhi harga jual dan laba UMKM Eraclassic. Harga jual yang ditetapkan dan laba yang diharapkan akan diperoleh menjadi terlalu rendah apabila harga pokok produksi yang dtentukan oleh UMKM Eraclassic lebih kecil dibandingkan dengan harga pokok yang dihitung menggunakan metode job order costing. Begitupun sebaliknya.

Berikut perhitungan harga pokok produksi berdasarkan metode job order costing (Mulyadi, 2012: 40) dimana total harga pokok pesanan dihitung dengan unsur biaya sebagai berikut.

\section{Biaya produksi pesanan:}

Taksiran biaya bahan baku $\mathrm{XxX}$

Taksiran biaya tenaga kerja langsung $\mathrm{xxx}$

Taksiran biaya overhead pabrik $\quad \underline{\mathrm{xxx}}+$

Taksiran biaya produksi

$\mathrm{XXX}$

Biaya nonproduksi:

Taksiran biaya administrasi \& umum $\mathrm{xxx}$

$\begin{array}{ll}\text { Taksiran biaya pemasaran } & \underline{\mathrm{xxx}}+ \\ \text { Taksiran biaya nonproduksi } & \underline{\mathrm{xxx}}+ \\ \text { Taksiran total harga pokok pesanan } & \mathrm{xxx}\end{array}$

Taksiran total harga pokok pesanan $\quad$ xxx.

\section{Hasil dan Pembahasan}

\section{Hasil}

\section{Proses Produksi}

Proses produksi yang dilakukan oleh UMKM Eraclassic diawali dengan diterimanya pesanan dari pelanggan. Berdasarkan pesanan tersebut kemudian dilakukan pembelian kain dan bahan baku. Setelah itu, dilakukan pemotongan pola pada kain dan bahan baku lainnya. Kain yang telah dipotong dengan pola tertentu beserta bahan baku lainnya dijadikan satu dan dihitung per lusin untuk nantinya diberikan ke penjahit. Tas yang sudah jadi kemudian disetorkan oleh penjahit ke UMKM Eraclassic untuk di lakukan packing yang merupakan akhir dari proses produksi.

\section{Pembahasan}

Pada Bulan Juli UMKM Eraclassic menerima tiga jenis pesanan, meliputi tas selempang, tas gaul, dan tas ransel. Dampak dari proses produksi berdasarkan pesanan adalah hasil perhitungan harga pokok produksi yang berbada untuk setiap pesanannya. UMKM Eraclassic menghitung harga pokok produksi dengan menjumlahkan biaya bahan baku, biaya tenaga kerja langsung, biaya tenaga kerja tidak langsung dan biaya lain-lain yang meliputi biaya listrik dan Telepon. Berdasarkan perhitungan tersebut kemudian dapat diketahui harga pokok produksi tiap pesanan maupun harga pokok produksi per unit produk dalam tiap pesanan. Perhitungan tersebut dilakukan sendiri oleh UMKM Eraclassic dan peneliti kemudian akan melakukan perhitungan ulang atau melakukan rekonstruksi menggunakan pendekatan full costing dengan metode job order costing. Dari hasil perhitungan harga pokok produksi kemudian akan dilakukan analisis dampaknya terhadap harga jual dan laba. Rekonstruksi harga pokok produksi dalam penelitian ini akan dilakukan terhadap tiga pesanan yang dikerjakan di bulan Juli 2016.

\section{Perhitungan Harga Pokok Produksi Menurut UMKM Eraclassic}

UMKM Eraclassic menghitung harga pokok produksi dengan menjumlahkan biaya-biaya produksi yang meliputi biaya bahan baku, biaya tenaga kerja dan biaya lain-lain.Biaya bahan baku yang dibebankan pada produk oleh UMKM Eraclassic merupakan biaya yang dikeluarkan untuk membeli bahan baku hingga bahan tersebut siap digunakan dalam proses produksi.

UMKM Eraclassic dalam melakukan pembebanan upah tenaga kerja pada produk menggunakan tarif yang telah ditetapkan. Pembebanan upah tukang potong dan tenaga kerja bagian packing masing-masing sebesar Rp 15.000 dan pembebanan untuk upah bagian administrasi sebesar dan Rp 7.000. Semua jenis pesanan akan dibebankan upah tukang potong, bagian packing dan bagian administrasi dengan jumlah yang sama. Hal ini merupakan kebijakan dari UMKM Eraclassic terkait pembebanan upah tersebut pada produk. UMKM Eraclassic menilai bahwa pembebanan dengan upah tenaga kerja dengan nilai tersebut sudah bisa menutupi jumlah biaya tenaga kerja yang dikeluarkan untuk melakukan kegiatan produksi.

UMKM Eraclassic juga membebankan upah penjahit pada produk. Upah penjahit bersifat borongan dan dibebankan berbeda untuk setiap pesanannya tergantung dari kesulitan spesifikasi tas. Semakin rumit spesifikasi tas nya, maka semakin besar upah penjahit yang dibebankan seiring semakin besar pula upah yang diberikan kepada penjahit. Berdasarkan tabel diatas dapat diketahui bahwa UMKM Eraclassic membebankan upah penjahit pada pesanan tas selempang, pesanan tas gaul dan pesanan tas ransel masingmasing sebesar Rp 45.000, Rp 85.000 dan Rp 97.000 per lusinnya. Pesanan tas ransel memiliki kerumitan dalam menjahit yang lebih jika dibandingkan dengan dua pesanan lainnya, sehingga upah yang diberikan kepada penjahit lebih besar jika dibandingkan dengan upah untuk tas selempang dan tas ransel.

Selain biaya bahan baku dan biaya tenaga kerja, UMKM Eraclassic juga membebankan biaya lain-lain pada pesanan. Biaya lain-lain yang dibebankan pada pesanan meliputi biaya 
listrik dan telp. UMKM Eraclassic dalam memproduksi pesanan membutuhkan listrik untuk melakukan pemotongan kain yang menggunakan gunting listrik dan untuk aktivitas lainnya yang berkaitan dengan produksi. UMKM Eraclassic tidak menggunakan telp namun menggunakan handphone dalam berkomunikasi dengan konsumen maupun suplier bahan baku. Biaya telp yang dibebankan merupakan estimasi biaya pulsa yang dikeluarkan oleh UMKM Eraclassic untuk berkomunikasi dengan pemesan maupun suplier bahan baku yang berkaitan dengan pesanan yang diterima. Tabel diatas menunjukkan bahwa UMKM Eraclassic membebankan biaya lain-lain untuk setiap pesanan sebesar Rp 15.000 per lusinnya dan pembebanan ini nilainya bersifat tetap untuk semua jenis pesanan.

Tabel 1. HPP dan Harga Jual Tas Selempang, Tas Gaul, dan tas ransel berdasarkan perhitungan UMKM Eraclassic

\begin{tabular}{lccccc}
\hline \multicolumn{1}{c}{ Jenis Pesanan } & \multicolumn{2}{c}{ HPP } & \multicolumn{2}{c}{ Harga Jual } \\
\hline Tas Selempang & Rp & 21,933 & Rp & 26,320 \\
Tas Gaul & Rp & 29,442 & & Rp & 35,330 \\
Tas Ransel & Rp & 40,960 & Rp & 49,153
\end{tabular}

\section{Perhitungan Harga Pokok Produksi Berdasarkan Metode} Job Order Costing

Biaya bahan baku yang dihitung menggunakan metode job oerder costing memiliki nilai yang sama dengan perhitungan biaya bahan baku yang dilakukan oleh UMKM Eraclassic. Biaya tenaga kerja langsung merupakan biaya yang dikeluarkan untuk membayar tenaga kerja yang sifat pekerjaannya berhubungan langsung dengan produk. Biaya tenaga kerja langsung pada UMKM Eraclassic meliputi ongkos penjahit, tukang potong dan bagian packing. Perhitungan biaya tenaga kerja dibebankan pada produk yang dilakukan oleh UMKM Eraclassic memiliki hasil yang berbeda dengan perhitungan yang dilakukan peneliti. Hal ini disebabkan karena penggolongan biaya tenaga kerja langsung dan perbedaan cara pembebanan upah tenaga kerja pada produk.

Pembebanan yang dilakukan oleh UMKM Eraclassic berdasarkan kebijakan biaya yang telah ditentukan sendiri oleh UMKM Eraclassic, bukan dibebankan berdasarkan biaya yang dikeluarkan. Seharusnya biaya tenaga kerja langsung dibebankan sesuai dengan biaya yang dikeluarkan untuk membayar upah tenaga kerja. Selain itu, tenaga kerja bagian administrsi juga seharusnya tidak digolongkan sebagai komponen tenaga karja langsung. Hal ini disebabkan yang merupakan tenaga kerja langsung adalah tenaga kerja yang berhubungan langsung dengan produk dalam proses produksi.

Upah tersebut dibayarkan pada tenaga kerja untuk mengerjakan semua pesanan yang meliputi tas selempang, tas gaul dan tas ransel, sehingga harus dilakukan pembebanan dengan tarif. Peneliti dalam membebankan upah tenaga kerja tukang potong dan packing dengan cara membagi total upah tenaga kerja per bulannya dengan estimasi unit diproduksi per bulan. Dengan demikian dapat diketahui pembebanan upah tenaga kerja per unit. Biaya yang tidak digolongkan kedalam biaya bahan baku dan biaya tenaga kerja langsung akan dimasukkan sebagai unsur biaya overhead pabrik.
Biaya overhead pabrik pada UMKM Eraclassic meliputi biaya penyusutan gedung, biaya penyusutan mobil, biaya penyusutan peralatan pabrik, biaya bahan penolong plastik packing serta biaya listrik dan telp. Peneliti menghitung biaya overhead pabrik menggunakan dasar pembebanan unit diproduksi. Pembebanan Bop per unit dihitung dengan cara membagi total biaya overhead pabrik yang dianggarkan dengan estimasi unit diproduksi.

UMKM Eraclassic tidak menghitung biaya overhead pabrik, namun memperhitungkan biaya lain-lain dalam perhitungan harga pokok produksinya. Dapat dikatakan bahwa biaya overhead pabrik menurut UMKM Eraclassic adalah biaya lain-lain. Unsur biaya lain-lain dalam perhitungan yang dilakukan oleh UMKM Eraclassic meliputi biaya listrik dan telp. UMKM Eraclassic tidak memperhitungkan biaya penyusutan aset tetap, biaya bahan penolong maupun biaya kas dikeluarkan karena proses produksi sebagai unsur biaya overhead pabrik.

Tabel 2. HPP dan Harga Jual Tas Selempang, Tas Gaul, dan Tas Ransel Per Unit Berdasarkan Metode JOC

\begin{tabular}{lcccc}
\hline \multicolumn{1}{c}{ Jenis Pesanan } & \multicolumn{2}{c}{ HPP } & Harga Jual \\
\hline Tas Selempang & Rp & 22,680 & Rp & 27,216 \\
Tas Gaul & Rp & 30,189 & Rp & 36,227 \\
Tas Ransel & Rp & 41,707 & Rp & 50,049
\end{tabular}

\section{Analisis Dampak Perbedaan Perhitungan Harga Pokok Produksi Terhadap Harga Jual Dan Laba}

Berdasarkan hasil perhitungan yang dilakukan oleh UMKM Eraclassic dan peneliti terdapat perbedaan. Perbedaan hasil perhitungan harga pokok produksi tersebut nantinya pasti berdampak terhadap harga jual dan laba. Perbedaan hasil perhitungan harga pokok produksi diatas secara otomatis akan berdampak pada harga jual dan laba pada masingmasing pesanan. UMKM Eraclassic menentukna harga jual dengan cara melakukan mark up biaya sebesar 20\% dari harga pokok produksi. Dengan demikian jika hasil perhitungan harga pokok produksi yang dihitung oleh UMKM Eraclassic dengan penenliti berbeda, maka perhitungan harga jual juga akan memberikan hasil yang berbeda.Harga jual yang dihitung dengan metode perusahaan jika dibandingkan dengan perhitungan peneliti maka akan terdapat selisih.

UMKM Eraclassic dalam menentukan harga jual untuk tas selempang, tas gaul dan tas ransel terlalu rendah sebesar Rp 10.753 per lusinnya. Hal ini menunjukkan bahwa harga jual yang ditetapka oleh UMKM Eraclassic terlalu rendah sebesar selisih tersebut jika dibandingkan dengan perhitungan berdasarkan metode job order costing. Selain terhadap harga jual, perbedaan perhitungan harga pokok produksi yang dilakukan oleh UMKM Eraclassic dengan perhitungan yang dilakukan oleh peneliti juga secara otomatis akan berdampak terhadap laba yang diterima. Laba yang diterima oleh UMKM Eraclassic untuk semua pesanan masing-masing jenis tas apabila dihitung menggunakan metode UMKM Erclassic maka terlalu rendah sebesar Rp 1.792 per lusinnya. 
Menurut peneliti, UMKM Eraclassic lebih tepat jika menerapkan metode job order costing dalam menghitung harga pokok produksi. Hal ini dikarenakan penerapan metode job order costing akan lebih mendukung dibadingkan dengan perhitungan yang dilakukan perusahaan, salah satunya dalam hal identifikasi biaya. Setiap pesanan memiliki spesifikasi yang berbeda, sehingga pengklasifikasian biaya produksi tiap pesanan menjadi penting untuk dilakukan agar harga pokok produksi yang dilakukan lebih akurat. Penerapan metode job order costing dalam perhitungan harga pokok produksi akan lebih mencerminkan biaya produksi dibandingkan dengan perhitungan yang selama ini dilakukan oleh UMKM Eraclassic.

Metode job order costing lebih memperhitungkan semua biaya produksi sehingga UMKM Eraclassic dapat mengetahui keseluruhan biaya yang berhubungan dengan produksi. Apabila terdapat pembengkakan biaya produksi, UMKM Eraclassic dapat menganalisis penyebab dari pembengkakan biaya tersebut kemudian melakukan pengendalian terhadapnya dan melakukan efisiensi biaya. Selain itu, dengan menerapkan metode job order costing menjadikan laba UMKM Eraclassic lebih besar yang akan berguna untuk pelaporan eksternal. Jika nanti UMKM Eraclassic melakukan pinjaman, peningkatan laba akibat penerapan metode job order costing akan membantu meyakinkan pemberi pinjaman bahwa UMKM Eraclassic mampu untuk membayar hutang nantinya sehingga layak untuk diberi pinjaman.

Penerapkan metode job order costing membuat harga jual tas selempang, tas gaul dan tas ransel pada UMKM Eraclassic lebih tinggi dibandingkan dengan harga jual yang dihitung oleh UMKM Eraclassic sendiri. Namun berdasarkan rekonstruksi yang dilakukan oleh peneliti dalam penelitian ini, kenaikan harga jual akibat penerapan metode job order costing dalam perhitungan harga pokok produksi tidak begitu jauh dari harga jual yang ditetapkan oleh UMKM Eraclassic, sehingga besar kemungkinan produk UMKM Eraclassic masih bisa bersaing di pasar meskipun menerapka metode job order costing dalam perhitungan harga pokok produksinya menyebabkan kenaikan harga jual.

Peneliti telah membandingkan harga jual atas tas selempang, tas gaul dan tas ransel pada UMKM Eraclassic yang dihitung menggunakan metode job order costing dengan harga jual tas yang serupa dengan kualitas yang sama pada tiga UMKM pengrajin tas lainnya Di kabupaten Gresik. Peneliti memperoleh informasi mengenai harga jual tas yang serupa dengan tas selempang, tas gaul dan tas ransel yang diproduksi oleh UMKM Eraclassic pada tiga UMKM pengrajin tas Di Kab.Gresik kemudian melakukan perbandingan.

Tabel 3. Perbandingan Harga Tas Selempang, Tas Gaul, dan Tas Ransel

\begin{tabular}{lccc}
\hline $\begin{array}{l}\text { Pemilik } \\
\text { UMKM }\end{array}$ & $\begin{array}{c}\text { Tas } \\
\text { Selempang }\end{array}$ & Tas Gaul & Tas Ransel \\
\hline UMKM & Rp 326.593 & Rp 434.723 & Rp 600.583
\end{tabular}

Eraclassic

\begin{tabular}{|c|c|c|c|c|}
\hline $\begin{array}{l}\text { Bpk. } \\
\text { Wahib }\end{array}$ & H. & Rp 339,657 & $\operatorname{Rp} 425,159$ & $\operatorname{Rp} 607,790$ \\
\hline $\begin{array}{l}\text { Bpk. } \\
\text { Alikasan }\end{array}$ & H. & Rp 334,758 & Rp 444,287 & $\operatorname{Rp} 608,511$ \\
\hline Bpk. Rozy & & Rp 322,674 & Rp 429,941 & $\operatorname{Rp} 593,256$ \\
\hline
\end{tabular}

Tabel di atas menunjukkan bahwa harga tas pada UMKM Eraclassic yang dihitung menggunakan metode job order costing tidak berada dibawah maupun diatas harga tas pada tiga UMKM lainnya, dengan kata lain harga tersebut masih bisa diterima pasar. Hal ini menunjukkan bahwa penerapan metode job order costing akan menaikkan harga jual tas selempang, tas gaul dan tas ransel pada UMKM Eraclassic namun kenaikan harga jual tersebut masih dalam range harga pasar. Dengan demikian UMKM Eraclassic masih bisa bersaing di pasar dan tidak kehilangan konsumennya meskipun ada kenaikan harga jual.

Harga jual tas selempang, tas gaul dan tas ransel pada UMKM Eraclassic tidak merupakan harga tas terendah ataupun tertinggi jika dibandingkan dengan harga tas dengan jenis yang serupa pada tiga UMKM pengrajin tas lainnya. Oleh karenanya peneliti menyarankan UMKM Eraclassic untuk menerapkan metode job order costing dalam perhitungan harga pokok produksinya.

\section{Simpulan}

Kesimpulan yang dapat diambil dari hasil penelitian terkait dengan perhitungan harga pokok produksi UMKM Eraclassic berdasarkan metode job order costing beserta pengaruhnya terhadap harga jual dan laba adalah sebagai berikut.

UMKM Eraclassic melakukan perhitungan harga pokok produksi dengan menjumlahkan biaya bahan baku, biaya tenaga kerja dan biaya lain-lain. Terdapat ketidak sesuaian dalam menggolongkan dan membebankan biaya tenaga kerja dan biaya overhead pabrik. Hasil perhitungan harga pokok produksi pesanan tas selempang, tas gaul dan tas ransel adalah masing-masing sebesar Rp 21.933, Rp 29.442 dan Rp 40.960 per unitnya.

Peneliti melakukan rekonstruksi perhitungan harga pokok produksi berdasarkan metode job order costing pada UMKM Eraclassic. Peneliti memperhitungkan semua unsur biaya yang dikeluarkan untuk melakukan proses produksi pesanan tas selempang, tas gaul dan tas ransel.

\section{Referensi}

Mulyadi, 2012.Akuntansi Biaya, Edisi 5. Yogyakarta: UPP STIM YKPN.

Siregar, Suripto, Hapsoro, Lo, Herowati, Kusumasari, dan Nurofik. 2014. Akuntansi Biaya, Edisi 2. Jakarta: Salemba Empat

Sudaryanto et.al. 2012. Strategi Pemberdayaan UMKM Menghadapi Pasar Bebas Asean.

Sugiyono, 2013. Statistika Untuk Penelitian. Bandung: Alfabeta. 